\title{
Uji Aktivitas Antibakteri dan Sitotoksik Ekstrak Metanol Aglaia silvestris (M.Roemer) Merr.
}

\author{
Antibacterial dan Cytotoxic Activities of Aglaia silvestris (M.Roemer) Merr. Methanol \\ Extract
}

Praptiwi

Bidang Botani, Puslit Biologi - LIPI, Bogor, Jl. Ir. H. Juanda 22, Bogor 16122

Telp :0251-324616,E-mail : praptiwip@yahoo.com

\begin{abstract}
The antibacterial and sitotoxic activities of ganggo (Aglaia silvestris (M.Roemer) Merr. methanol extract were determined in this study. Antibacterial in-vitro test of ganggo methanol extract was exposed to Gram positive (Staphylococcus aureus ATCC 25923, Streptococcus agalactiae ATCC 8190, and Streptococcus sp.) and Gram negative (Salmonella typhii NCTC 786 E, Eschericia coli ATCC 25922, and Pseudomonas pseudomallei ATCC 15682) bacteria. The extract concentrations were 50, 25 and $12.5 \%$, and done in triplicate. The growth inhibition area of extract was compared to those of standard antibiotic (10 unit ampicilin). Cytotoxic test of ganggo extract was done utilizing Brine Shrimp Lethality Test (BST) with Artemia salina.The result showed that growth inhibition area of $12.5 \%$ ganggo methanol extract to $P$. pseudomallei $(19 \mathrm{~mm})$ was wider than that of 10 unit ampicilin $(0 \mathrm{~mm})$. It showed that $P$. pseudomallei was sensitive to ganggo methanol extract. The result of BST showed that $\mathrm{LC}_{50}$ of ganggo extract was $345.44 \mathrm{ppm}$. It was concluded that ganggo methanol extract had antibacterial effects on some bacteria isolates and had cytotoxic effects with $L_{50} 345.44 \mathrm{ppm}$.
\end{abstract}

Key words: Aglaia silvestris, growth inhibition area, cytotoxic activity

Diterima: 09 Juni 2005, disetujui: 02 Agustus 2006

\section{Pendahuluan}

Bakteri merupakan suatu mikroorganisme yang dapat berdampak positif atau negatif pada tubuh manusia. Bakteri patogen, yang dapat menyebabkan suatu penyakit tertentu merupakan bakteri yang merugikan. Penyakit yang disebabkan oleh bakteri biasanya ditanggulangi dengan pemberian antibiotika. Tetapi, pada saat ini timbul masalah resistensi bakteri terhadap beberapa antibiotika yang telah umum digunakan. Oleh sebab itu perlu penggalian sumber bahan obat yang berasal dari sumber daya hayati yang mengandung komponen kimia yang dapat mengatasi masalah resistensi bakteri.
Di lain pihak, beberapa jenis tumbuhan secara tradisional telah dimanfaatkan sebagai tumbuhan obat di antaranya tumbuhan dari marga Aglaia. Aglaia terdiri dari 105 jenis dan terdapat kemungkinan masih ada jenis baru. Di Sumatra telah ditemukan 38 jenis Aglaia (Widodo, 2003). Beberapa jenis Aglaia telah dimanfaatkan secara tradisional sebagai tumbuhan obat, misal daunnya untuk mengobati luka, sedang kulit batangnya untuk pengobatan tumor. Beberapa komponen kimia yang bersifat bioaktif dari beberapa jenis Aglaia juga telah diketahui (Widodo, 2003). A.basophylla mengandung komponen kimia flavagline yang bermanfaat sebagai insektisida (Greger et al., 2001).

Salah satu jenis Aglaia adalah ganggo (Aglaia silvestris). Tumbuhan ini merupakan 
pohon besar dengan tinggi dapat mencapai 30$50 \mathrm{~m}$ (Heyne, 1987). Ganggo (Aglaia silvestris) telah diketahui mengandung komponen kimia silvestrol dan episilvestrol yang potensial sebagai antikanker (Hwang et al., 2004). Berdasarkan hal tersebut di atas maka dilakukan uji antibakteri secara in-vitro untuk mengetahui sifat antibakteri ekstrak metanol ganggo terhadap beberapa isolat bakteri Gram positif dan bakteri Gram negatif.

Sifat bioaktif ekstrak tumbuhan pada umumnya berkaitan dengan komponen kimia pada tumbuhan tersebut. Komponen kimia yang bersifat bioaktif dapat dimanfaatkan pada dosis dan konsentrasi yang tepat tetapi pada dosis yang tidak tepat terdapat kemungkinan akan bersifat toksik. Sifat toksik suatu ekstrak dapat dilakukan secara cepat dan murah dengan Brine Shrimp Lethality Test (BST) sehingga dapat diketahui $\mathrm{LC}_{50}$ dari suatu ekstrak. Pada penelitian ini juga dilakukan BST terhadap ekstrak methanol ganggo.

\section{Metode Penelitian}

\section{Ekstraksi}

Kulit batang ganggo (A. silvestris) yang telah dibersihkan kemudian dikeringanginkan, dan digiling untuk dibuat serbuk. Serbuk ditimbang sebanyak 500 gram, setelah itu dimaserasi dengan $1.5 \mathrm{~L}$ metanol selama 24 jam, kemudian disaring dan filtratnya ditampung. Hal ini dilakukan sampai filtrat yang tertampung tidak berwarna. Filtrat yang ada dipekatkan dengan rotary-evaporator sehingga diperoleh ekstrak pekat kemudian dikeringkan. (Harborne, 1984). Ekstrak pekat yang diperoleh dianalisis komponen kimianya dengan metode penapisan fitokimia (Cuiley, 1984)

\section{Uji Antibakteri}

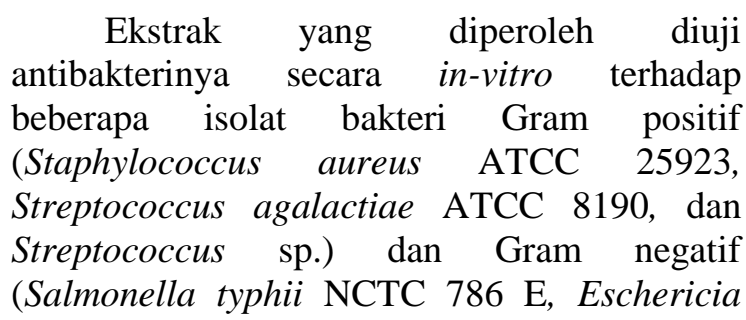

coli ATCC 25922, dan Pseudomonas pseudomallei ATCC 15682) pada konsentrasi bakteri lebih kurang $10^{6}$. Konsentrasi ekstrak yang diuji adalah 50, 25, dan 12,5\%. Tiap-tiap konsentrasi dilakukan dalam 3 ulangan. Selanjutnya $15 \mu \mathrm{l}$ ekstrak diteteskan pada kertas cakram steril dan diletakkan pada medium Mueller Hinton Agar (MHA) yang telah diinokulasi dengan isolat bakteri uji. Medium MHA yang telah diinokulasi selanjutnya diinkubasi pada suhu $37^{\circ} \mathrm{C}$ selama 24 jam. Sifat antibakteri ditunjukkan dengan adanya daerah bening di sekitar keretas cakram yang menunjukkan adanya penghambatan pertumbuhan bakteri (Simmons \& Craver, 1980).

\section{Uji Sitotoksik/ Brine Shrimp Lethality} Test (Dey \& Harborne, 1991)

\section{Persiapan bahan uji}

Ekstrak yang akan diuji sitotoksiknya dibuat larutan dengan konsentrasi 2000, 1000, 100, dan 10 ppm menggunakan dimetil sulfoksida (DMSO) dan air laut. Masingmasing konsentrasi dibuat sebanyak 3 ulangan dengan volume $5 \mathrm{ml}$ pada masing-masing vial yang telah ditandai pada volume $10 \mathrm{ml}$.

\section{Penetasan larva Artemia salina (Leach)}

Telur A.salina ditimbang sebanyak 50 mg kemudian dimasukkan dalam "beaker glass" yang berisi air laut buatan (3,8 gram garam kasar tidak beriodium dilarutkan dalam 1 liter akuades). Beaker glass tersebut ditutup sebagian untuk diberi cahaya, dibiarkan selama 3 hari, sehingga telur tersebut menetas menjadi larva yang digunakan untuk uji sitotoksik.

\section{Uji terhadap larva}

Larva diambil dengan pipet dan dimasukkan sebanyak 10 ekor pada masingmasing vial dari masing-masing konsentrasi. Volume pada masing-masing vial dibuat menjadi $10 \mathrm{ml}$, kemudian dibiarkan selama 24 jam. Hari berikutnya diamati jumlah larva yang masih hidup pada masing-masing konsentrasi. Sifat sitotoksik dihitung berdasarkan $\mathrm{LC}_{50}$ dan data dianalisis dengan Probit Finney. 


\section{Hasil dan Pembahasan}

\section{Penapisan fitokimia}

Sifat bioaktif suatu tumbuhan pada umumnya berkaitan dengan komponen kimia yang terdapat pada tumbuhan tersebut (Robinson, 1991). Hal ini dimaksudkan untuk mendapatkan ekstrak yang mengandung komponen kimia dengan kepolaran yang berbeda secara optimum. Kochhar dan Russel (1990) menyatakan bahwa kandungan kimia dari suatu tumbuhan hanya dapat terlarut pada pelarut yang sama kepolarannya, sehingga suatu golongan senyawa dapat dipisahkan dari senyawa lainnya. Kandungan kimia tersebut dapat diidentifikasi antara lain dengan cara penapisan fitokimia pada ekstrak eter, alkohol, dan air (Cuiley, 1984). Berdasarkan hasil penapisan fitokimia maka kandungan senyawa kimia pada kulit batang Aglaia silvestris adalah sebagai berikut (Tabel 1).

\section{Uji in-vitro antibakteri}

Uji antibakteri ekstrak metanol ganggo terhadap beberapa isolat bakteri Gram negatif dan Gram positif terdapat pada Tabel 2.

Tabel 1. Senyawa kimia pada kulit batang A. silvestris berdasarkan penapisan fitokimia

\begin{tabular}{clc}
\hline \hline No & \multicolumn{1}{c}{ Senyawa } & Hasil uji \\
\hline \hline 1 & Minyak atsiri & - \\
2 & Lemak dan asam lemak & - \\
3 & Sterol dan triterpen & + \\
4 & Karotenoida & - \\
5 & Alkaloid basa & + \\
6 & Aglikon flavon & - \\
7 & Emodol (Aglikon antrasenoid) & + \\
8 & Tanin & + \\
& -Katekol & - \\
9 & -Galat & + \\
10 & Gula pereduksi & + \\
11 & Antrasenoid & + \\
12 & Derivat kumarin & - \\
13 & Glikosida steroid & - \\
14 & Glikosida jantung & + \\
15 & Flavonoid & - \\
16 & Poliuronida & - \\
17 & Saponin & + \\
\hline \hline
\end{tabular}

Keterangan : + : terdeteksi

- : tidak terdeteksi

Tabel 2. Diameter daerah hambat (DDH) pertumbuhan isolat bakteri pada ekstrak metanol ganggo

\begin{tabular}{lcccc}
\hline \hline Isolat bakteri & \multicolumn{4}{c}{ Diameter Daerah Hambat (DDH) pada konsentrasi ekstrak } \\
& $\mathbf{5 0 \%}$ & $\mathbf{2 5 \%}$ & $\mathbf{1 2 . 5 \%}$ & Ampisilin 10 unit \\
\hline \hline Staph. aureus & 14,00 & 13,67 & 12,67 & 36,00 \\
Strep. agalactiae & 9,00 & 8,00 & 7,00 & 13,50 \\
Streptococcus sp. & 10,67 & 10,67 & 9,67 & 15,00 \\
S. typhii & - & - & - & - \\
E. coli & - & - & - & 13,50 \\
P. pseudomallei & $\mathbf{2 5 , 6 7}$ & $\mathbf{2 1 , 6 7}$ & $\mathbf{1 9 , 0 0}$ & - \\
\hline \hline
\end{tabular}


Hasil pada Tabel 2 menunjukkan bahwa ekstrak metanol ganggo menghambat pertumbuhan 3 isolat bakteri Gram positif meskipun daya hambat pertumbuhannya lebih kecil dari ampisilin 10 unit. Penghambatan pertumbuhan pada bakteri Gram negatif hanya terdapat pada $P$. pseudomallei, sedangkan 10 unit ampisilin tidak menghambat pertumbuhan $P$. pseudomallei. Penghambatan pertumbuhan pada isolat bakteri Gram negatif kemungkinan lebih sulit karena struktur membran sel bakteri Gram negatif berlapis-lapis dan sangat kompleks (Jawetz et al., 1996). Kemampuan penghambatan pertumbuhan isolat bakteri oleh ekstrak ganggo tersebut berkaitan dengan komponen kimia yang kemungkinan bersifat sebagai antibakteri. Komponen kimia pada ganggo adalah lemak dan asam lemak, tannin, gula pereduksi, glukosida dan saponin. Dari beberapa komponen kimia tersebut kemungkinan yang dapat bersifat antibakteri adalah tanin yang merupakan senyawa polifenol.

Penghambatan pertumbuhan paling besar terlihat pada isolat bakteri $P$. pseudomallei, yang menunjukkan bahwa isolat bakteri tersebut merupakan isolat yang paling sensitif terhadap ekstrak metanol ganggo. Pada dua isolat bakteri Gram negatif lain yang diuji ternyata ekstrak metanol ganggo tidak membentuk daerah penghambatan pertumbuhan. Hal ini mungkin disebabkan isolat tersebut telah resisten terhadap antibiotika standar atau senyawa kimia yang berfungsi sebagai antibakteri konsentrasinya rendah. Hasil pada Tabel 2 juga menunjukkan bahwa konsentrasi ekstrak mempengaruhi diameter daerah hambat pada masing-masing isolat. Makin besar konsentrasi ekstrak maka makin besar pula diameter daerah hambat pertumbuhan bakteri, yang menunjukkan meningkatnya konsentrasi ekstrak meningkat pula senyawa kimia yang dapat bersifat antibakteri.

\section{Uji sitotoksik}

Pengamatan sitotoksisitas dilakukan setelah larva A. salina dibiarkan pada air laut yung ditambah berbagai konsentrasi ekstrak. Hasil uji sitotoksisitas pada ekstrak ganggo dengan metode $\mathrm{BST}$ menunjukkan bahwa $\mathrm{LC}_{50}$ adalah 345,66 ppm. Pada konsentrasi 345,66 ppm maka populasi larva udang akan mati sebanyak 50\%. Jadi ekstrak tersebut bersifat sitotoksik karena mempunyai nilai $\mathrm{LC}_{50}$ kurang dari 1000 ppm.

\section{Kesimpulan}

Dari Penelitian di atas dapat disimpulkan bahwa ekstrak metanol ganggo mempunyai daya hambat terhadap 3 isolat bakteri Gram positif yang diuji (Staphylococcus aureus ATCC 25923, Streptococcus agalactiae ATCC 8190, dan Streptococcus sp.) berturut-turut adalah 12,$67 ; 7,00$ dan $9,67 \mathrm{~mm}$ pada konsentrasi ekstrak 12,5\%. Isolat bakteri Gram negatif yang dihambat pertumbuhannya adalah $P$. pseudomallei dengan diameter daerah hambat 19.00 pada konsentrasi 12,5\% ekstrak. Isolat yang paling sensitif terhadap ekstrak metanol ganggo adalah $P$. pseudomallei $\mathrm{LC}_{50}$ ekstrak methanol ganggo adalah 345,44 ppm terhadap larva Artemia salina.

\section{Daftar Pustaka}

Cuiley, J. 1984. Methodology for Analysis of Vegetables and Drugs. Fac. of Pharmacy. Bucharest. Rumania

Dey, P.M. and Harborne, J.B. 1991. Methods in Plant Biochemistry vol 6: Assays for Bioactivity. Academic Press. London.

Greger, H., Pacher, T., Brem, B., Bacher, M. and Hofer, O. 2001. Insecticidal Flavaglines and Other Compounds from Fijian Aglaia Species. Phytochemistry 57(1) : 57-64.

Harborne, JB. 1984. Phytochemical Methods. Chapman and Hall. London.

Heyne, K. 1987. Tumbuhan Berguna Indonesia. Badan Penelitian dan Pengembangan Kehutanan. Departemen Kehutanan. Departemen Kehutanan, Indonesia.

Hwang, B.Y., Su, B.N., Chai, H., Mi, Q., Kardono, L.B., Afriastini, J.J., Riswan, S., Santarsiero, B.D., Mesecar, A.D., Wild, R., Fairchild, C.R., Vite, G.D., Rose, W.C., Farnsworth, N.R., Cordel, G.A., Pezzuto, J.M., Swanson, S.M., Kinghorn, A.D., Silvestrol and Episilvestrol. Potential Anticancer Rocaglate Derivatives from Aglaia silvestris. J. Org. Chem 69 (10) : 3310-8. 
Inad, A., Nishino, H., Kuchide, M., Takayasa, J., Mukainaka, T., Nobukuni, Y., Okuda, M. and Tokuda, H. 2001. Cancer Chemopreventive Activity of Odorine and Odorinol from Aglaia odorata. Biol Pharm Bull 24(11) :1282-1285.

Jawetz, E., Melnick, J., Adelberg, E. 1996. Medical Microbiology. Appleton \& Lange. Kochhar, SP and Russel, JB. (1990). Detection, Estimation and Evaluation of Antioxidant in Food System. In : Food Antioxidant. Elsevier Applied Science. London.

Mi, Q., Su, B.N, Chai, H., Cordell, G.A., Farnsworth, N.R., Kinghorn, A.D., Swanson, S.M. 2006. Rocaglaol Induces Apoptosis and Cell Cycle Arrest in LNCaP Cells. Anticancer Res. 26 (2A):947-952.

Rivero-Cruz, J.F., Chai, H.B., Kardono, L.B., Setyowati, F.M., Afriastini, J.J., Riswan, S., Farnsworth, N.R., Cordell, G.A., Pezzuto, J.M., Swanson, S.M., Kinghorn, A.D. 2004. Cytotoxic Constituents of the Twigs and Leaves of Aglaia rubiginosa. J. Nat. Prod.67(3): 343347.
Robinson, T. 1991. Kandungan Organik Tumbuhan Tinggi. Penerbit ITB. Bandung.

Simmons, C.G. and Craver, J. 1980. Antibiotic Sensitivity Test Using the Disk Method. Australian Beaureau Animal Health. Brisbane.

Su, B.N., Chai, H., Mi, Q., Riswan, S., Kardono, L.B., Afriastini, J.J., Santarsiero, B.D., Mesecar, A.D., Farnsworth, N.R., Cordell, G.A., Swanson, S.M., Kinghorn, A.D. 2006. Activity-Guided Isolation of Cytotoxic Constituents from the Bark of Aglaia crassinervia Collected In Indonesia. Bioorganic \& Medicinal Chemistry 14(4): 960-972.

Widodo, S.H. 2003. Aglaia lour. In : RHMJ Lemmens and N. Bunyapraphatsara (Eds.) Plant Resources of South-East Asia 12 (3) Medicinal and Poisonous Plants. Backhuys Publishers, Leiden. 